\title{
Application Of Social Capital In Poverty Allevation In Bruno District Of Purworejo Regency
}

\author{
Anita Rinawati ${ }^{1}$, Rusdarti $^{2}$, Etty Soesilowati ${ }^{2}$, Sucihatiningsih DWP $^{3}$ \\ \{anita@umpwr.ac.id, rusdarti@mail.unnes.ac.id, ettysoesilowati@mail.unnes.ac.id, \\ sucihatiningsih@mail.unnes.ac.id\}s \\ ${ }^{1}$ Universitas Muhammadiyah Purworejo Indonesia \\ ${ }^{2}$ Post Graduate Universitas Negeri Semarang Indonesia
}

\begin{abstract}
These research aims are to comprehend and analyze in the application of the social principal concept in the needy society area. It is to absolve them from the poverty at Tegalsari village, Bruno Sub-district, Purworejo District. This research is expected to decrease poverty in that area. It is by applying the social principal among society. This research is qualitative description. Where it is about case study method. The data is obtained by observing, surveying and deep interviewing. The informant selected is from a village government official, "GAPOKTAN" leader and the society from Tegalsari village at Bruno sub-district who are registered as the needy society. The research at the beginning is by identifying and analyzing the social principal in the needy society. After that, it is analyzed theoretically and empirical significantly at the social-economic condition. That is also about the social principal on the poverty area development and the social society alteration. The result shows that the social principal has a significant role to absolve poverty. Mainly, it is the relicense on needy society so that, it can strengthen the network element which exists in society. It can influence them to absolve them from poverty.
\end{abstract}

Keyword: Social Capital, village government, the society

\section{Introduction}

The Indonesian population has almost $40 \%$ agrarian sector as the occupation. It is also the life support of the Indonesian majority. However, the life of people from the agrarian sector (farmer) is not prosperous. That is also supported by Prajanti's [1] statement if from 28.60 million needy society, there is $63.25 \%$ rural population who are from the agrarian sector or as the farmer. Nowadays, farmers' condition is very apprehensive. The descent of farming has an impact on the land transition, and the policy is not on the farmer's side. As a result, they did not get prosperity.

The ability of production enhancement at the agrarian sector and absolve poverty depends on how they solve the obstacles on it. Some obstacles are on the land irrigation, the supreme variety of technology, the estimation preparation development and the intensive system preparation which drive the production enhancement and income to the farmer [2]. Moreover, Triyanto, also added the obstacles on the watering preparation, rainfall, climate and the inappropriate timing process of farming land [3], [4]. Those make the rice production result cannot be harvested at the right time and the result is not optimal. The research from Tanzania [5] had obstacles such as the instructor preparation, fertilizer and the distance from the village to market. 
The abuse of principal society to absolve poverty becomes one of the important component to support the human development model. It is because human is as the main subject to determine the successful development. The social principal needs autonomy to solve economic and social problems. Meanwhile, the assistance from the outside is as the supplement to drive an initiative and productivity from the society itself. It is as the creation of the visible human principle on the social society relationship. The social relationship or the community at the organization is determined by the trust keeping. It can be interpreted as the reliance on the related side among social relations in society. It can be concluded if the social principle has a close relationship with the social element communication.

Yulius Slamet [6] on his research had the alternative to solve the problem on the poverty in the rural farmers. It showed if the social principal approach can help to absolve poverty, [7] It was about the kinds of social principles to the development. It included the integrity aspect, the reliance, the open, has the high empathy and the values or the norms.

Purworejo District is one of the districts in Central Java. It has 16 sub-districts. The area is $1.034,81752 \mathrm{KM}^{2}$. It is bordering with Kebumen District in the west, Magelang and Wonosobo Districts in the north, Kulonprogo District in the east and Indonesia Ocean in the south. Based on the reference of Purworejo Regent number 188.4/364 year 2015 about the determination of village/"kelurahan" and the implementation of priority objective prevention poverty program, Purworejo District still has 59 villages on 16 sub-districts which are included to the red zone or the needy areas.

In line with the problems above, the aims of this research are: 1) identifying and analyzing the needy farmers' characteristic in Purworejo District, 2) Analyzing the farmer's social principal in the needy villages in Purworejo District.

\section{Research Methodology}

This research used qualitative approach. It is to find some impacts on the poverty problem exist. It is done to increase the society development. This research focused in Purworejo District which is on the red zone villages and sub-districts or the needy area. The prime data is obtained from the informant who is as the needy farmers' society representative, the farmer organization administrator, and the villages' officer from the red zone. In this case, the researchers did FGD (Focus Group Discussion). The secondary data is from "BPS" Purworejo District and the resources of villages' documentation. There are three steps to investigate in the data analysis such as the data reduction, display data and conclusion. Those are analyzed using the model analysis [8].

\section{Findings and Discussions}

This research is done in Tegalsari village on Bruno Sub-district, Purworejo. Burno Subdistrict is the part of Purworejo District at Central Java. The position is among $109^{\circ} 47^{\prime} 28^{\prime}$ ' $110^{\circ} 8^{\prime} 20^{\prime}$ ' east longitude and 7 32' - 7 54'" south longitude. The area is $108.43 \mathrm{KM}^{2}$. Where it consists of 18 villages. Bruno Sub-districts is the area on the plateau. This area is $75 \%$ mountains and hills with the high is $25-1050 \mathrm{M}$ above the sea level, the slope is $2-15 \%$ in a half area and $40 \%$ in the other area. 
From the respondents' information, there is another side occupation except for farmer. The following is the amount table and the percentage of the respondents who have the other side occupation (Table 1)

Tabel 1.The amount table and the percentage of the respondents who have the other side occupation

\begin{tabular}{lcc}
\hline The other occupation & Amount (people) & Percentage (\%) \\
\hline Didn't have other occupation & 25 & 62.5 \\
Seller & 8 & 20.0 \\
Builder & 6 & 15.0 \\
Retired & 1 & 2.5 \\
\hline Total & 40 & 100.0
\end{tabular}

Source : The prime date processed, 2018

Table 1 shows that $62.5 \%$ respondents do not have other occupation except the farmer. It means they only depend on the field harvest commodity. It includes the secondary crops which have a fluctuating price to support the farmers need in Tegalsari village. Other $20 \%$ respondents have a side occupation such as grocery and secondary crops sellers. $15 \%$ or 6 respondents are as builders. People who are like the builders will have more job in July, August, and September or if there is not on the secondary crops season.

The household poverty in Tegalsari Bruno can be placed in the third level based on the severity. There are very susceptible, susceptible and less susceptible. There is $10.23 \%$ on the poverty category household. $43.56 \%$ have the susceptible category, this has a very big needy possibility at the next year and $40.14 \%$ including to less susceptible category. This has poverty at the middle level. They can be needy if they have a low chance to enhance the prosperous next year.

The Analysis of Farmer Social Principal

1. The Reliance Level

This is about social bounding principal. It also has a strong bond and binding. Then, the relevant reliance indicator is used to see the strong bond inside society. The reliance level of farmers in Tegalsari village can be seen from the daily activity, like be able to share the experience with others. This activity is very high in its intention. However, some farmers who are following the other's suggestion in this village is not high, so that the reliance among them is medium.

2. The Allegiance Level in Social Norm

It is about the allegiance of farmers to the regulation in society. It can be on the tradition value or the local tradition. The social norm can be seen from the allegiance level of society to the tradition regulations or the local tradition. It can also on the religion norm. One of the examples is the cooperation in Tegalsari Bruno village-like building the environment road, the Indonesia independent's day celebration, and the others.

3. The Solid Network

The farmer household solid network measurement in Tegalsari village, at Bruno subdistrict is done by seeing the cooperation networking from one farmer to the others. It is also on the open of information or the advantages of association or farmer group organization. Based on the research before, it shows if the solid networking by the 
household farmer in Tegalsari village is on the medium level. It is alsoabout the social principal on the street vendors which have the solid networking relocation and supporting by the strong reliance so that they can survive inside the limit [9].

4. The Organization Participation in Environment

It has stressed at the six main elements in the social principal based on the understanding [10]. There is participation in a network. She also said the participation in a network is the ability of group people to include their selves in social networking. It can be on some parallel variations and it is done based on voluntary, equality, freedom and civility.

There are $65 \%$ of the household farmer participation in the medium level. While farmers' participation in Tegalsari village on the environment organization can be seen from the farmers' participation inside the organization. The farmers' who do not join inside is not high. They are on average only join in one or two organizations in their environment. Those can be formal and informal or the recitation group or "jamiahan" (the group on the religion norm).

5. if the social principal is the part of networking social life, norm, and reliance which drive the participant to reach the goals together [11]. The social principal role in enhancing the household economy prosperity is indirectly invisible. It is based on statement if the social principal is not about potency, or it can be directly transformed to the expected outcome so that it can be productive or has the role to increase the family economy development in some mechanisms [12]. The social principal in the household farmer has been utilized as the asset to get the production principal. It can be used to increase the prosperity of the household farmer. If there is broad household interaction in the organization so that prosperity is higher. This research shows if there is a relationship between the social principal and the social development to increase prosperity.

\section{Conclusion}

The essence of all groups' society has the socio-culture conductive potencies which can support the development. One of the potency is on the use of social principal.

The social principal is one of the farmers' assets in ensuring their life continuity. Not all of the social principal and the group farmer organization in Tegalsari village, Bruno sub-district are utilized by them. It is because of the farmer's perception if they join this organization, they will get nothing. The members of this group have to maximalist the farmer's group performance and socialize the benefits of this group to the farmers. On the other hand, the social principle has to be enhanced. The result of this research is the important role of social principal to absolve poverty. Mainly, in the holding reliance element on needy society, so that it can strengthen the networking which exists in society. It can also strengthen them in the pressing need. The enhancement of social principal is to support solid collective development andto make society more prosperous.

Acknowledgments. The author disclosed receipt of the financial support for the publication of this article. This research was sponsored by Purworejo Muhammadiyah University, Indonesia. 


\section{References}

[1] Prajanti, Sucihatiningsing Dian Wisika. 2013. Implementasi IT Cepat Saji Pembangunan Pertanian Dan Propagasi Ekonomi Pertanian Kreatif Untuk Meningkatkan Nilai Jual Petani. Pidato Pengukuhan Guru Besar UNNES.

[2] Sudaryanto, T., \& Rusastra, I. W. (2006). Kebijakan strategis usaha pertanian dalam rangka peningkatan produksi dan pengentasan kemiskinan. Jurnal Litbang Pertanian, 25(4), 115-122.

[3] Triyanto, J. (2006). Analisis produksi padi di Jawa Tengah (Doctoral dissertation, Program Pascasarjana Universitas Diponegoro)

[4] Amalia Dwi Marseva, Eka Intan Kumala Putri, Ahyar Ismail. (2016). Analisis Faktor Resiliensi Rumah Tangga Petani dalam Menghadapi Variabilitas Iklim. Jurnal Ekonomi dan Pembangunan Indonesia. Vol. 17 No. 1 Juli 2016: 15-27p-ISSN 1411-5212; e-ISSN 2406-9280. DOI: http://dx.doi.org/10.21002/jepi.v17i1.632

[5] Isham, J. (2000). The effect of social capital on technology adoption: evidence from rural Tanzania.

[6] Slamet, Yulius. 2011. Kemiskinan Petani Pedesaan. Analisis Mengenai Sebab-Sebab dan Alternatif Pemecahannya. Seminar Nasional Laboratorium Sosiologi. FISIP UNS.

[7] Inayah. 2012. Peranan Modal Sosial dalam Pembangunan. Jurnal Pengembangan Humaniora Vol. 12 No. 1, April 2012

[8] Maman,Rachman.2015, Lima Pendekatan Penelitian, Yogyakarta, Magnum Pustaka Utama.

[9] Handoyo, E. (2013). Kontribusi Modal Sosial dalam Meningkatkan Kesejahteraan Pedagang Kaki Lima Pascarelokasi. Komunitas: International Journal of Indonesian Society and Culture, 5(2).

[10] Hasbullah, J. (2006). Social Capital: menuju keunggulan budaya manusia Indonesia. MR-United Press.

[11] Field, J. (2010). Modal sosial. Bandung: Kreasi Wacana.

[12] Suandi.(2007). Modal Sosial dan Kesejahteraan Ekonomi Keluarga di Daerah Perdesaan Provinsi Jambi. Disertasi Institut Pertanian Bogor. 